\title{
Generating Politeknik Aceh Selatan Students Homeland GIS Map
}

\author{
Darma Setiawan Putra ${ }^{1}$, Alfahri Harriza ${ }^{2}$, Fardiansyah ${ }^{3}$ \\ 1,2,3 Program Studi Teknik Informatika, Politeknik Aceh Selatan \\ Jalan Merdeka, Kompleks Reklamasi Pantai, Tapaktuan 23751, Aceh Selatan, Indonesia \\ ${ }^{1}$ darma.poltas@gmail.com, ${ }^{2}$ fahrial.ramadhan98@gmail.com, ${ }^{3}$ fardian.poltas@gmail.com \\ *darma.poltas@gmail.com
}

Keyword:

Geographic Information System

Student's Homeland

CodeIgniter

Politeknik Aceh Selatan

WebGIS

\section{ABSTRACT}

Article history:

Accepted

\begin{abstract}
Nowadays, information is an essential element in life because every human activity and business needs it. One of the essential forms of information is geographic information that is used in the field of education. Geographic information is defined as a collection of data and facts about the phenomena of the earth, land, and its inhabitants in space and time. The geographical location of the South Aceh Polytechnic student's homeland is an essential data. If this information is managed properly, the leadership can find out the distribution of data from the students' homeland. The author designs and builds a Geographic Information System to manage student data from the South Aceh Polytechnic to find out the distribution of the homeland of the South Aceh Polytechnic students. This information system is designed using the PHP programming language with the CodeIgniter 3 Framework, MySQL, and the LeafletJS JavaScript Library. Testing the system using the Blackbox method. The results indicate that the system can run well by displaying markers of students' homeland on the map so that this information system can be utilized to determine the distribution of students' homeland effectively and efficiently.
\end{abstract}

Copyright (C) 2021 Politeknik Aceh Selatan. All rights reserved.

\section{Introduction}

Nowadays, information becomes an essential element in life because it is indispensable in almost every aspect of human life both for work and life planning. Good and accurate information will provide knowledge in determining a problem solving, planning and evaluation of what has been previously planned, one of which is geographical information.

Geographic information is defined as a collection of data or facts about the phenomena of the earth, soil, features, and inhabitants in space and time. Geography has two branches of study, namely human geography and physical geography, furthermore there are technical geography and regional planning. Human geography deals with the study of people and communities, cultures, economies and their interactions with the environment by studying their relationships with and across spaces and places. Physical geography deals with the study of processes and patterns in the natural environment such as the atmosphere, hydrosphere, biosphere, and geosphere [1]

South Aceh Polytechnic is one of the private universities in Indonesia in the form of a polytechnic, managed by the Higher Education and is included in Kopertis area 13. Currently Politeknik Aceh Selatan has 4 study programs, namely Industrial Engineering, Mechanical Engineering, Informatics Engineering and Computer Engineering [2]. Every Politeknik Aceh Selatan student has various kinds of information related to the geographic location of his or her area of origin. If the information on the distribution of the student's area of origin can be managed properly, then the leader can utilize the data formed from the distribution of the student's area of origin so that it can support the right decision making regarding the prospects of future students.

The development of digital-map database system software known as GIS, can be used in mapping the blood of students from a university or other educational institution. This information arrangement 
needs to be packaged in a geographic information system because this is an urgent need. Basically, every student has various kinds of information (non-spatial data) related to the geographic location information of their area of origin (spatial data). Of course, this information is needed by various parties, especially education providers. If the information on the distribution of the student's area of origin can be managed well, then the leadership can find out the groupings formed from the student's area of origin. From these groupings, an analysis can be made of how the regional distribution pattern of South Aceh Polytechnic students comes from and can then be used for decision making regarding the mechanisms and priorities of campus socialization programs [3].

\section{Literature Reviews}

Research [4] on geographic information systems has been carried out by many researchers. Researchers have conducted research to create a geographic information system to determine student mapping at the Faculty of Engineering, University of Muhammadiyah Ponorogo by utilizing the googlemap API as a library for javascript. The results of this study indicate that the homeland of the majority of students is in the Madiun residency area. Furthermore, researchers [5] have conducted research by creating a geographic information system to determine the distribution of students' homeland using the GoogleMap API. The results of this study indicate that the distribution of student homeland is displayed within the province in the form of tables and bar charts. Furthermore, researchers [6] have conducted research to create a geographic information system to determine the number of students at the University of Ubudiyah Indonesia using OpenStreet Map. The results of this study indicate that information on the number of students can be known from the information system which is marked based on the color of the map of the area displayed.

\section{Methods}

A. Chores

System design can be seen in the flowchart shown in Figure 1.

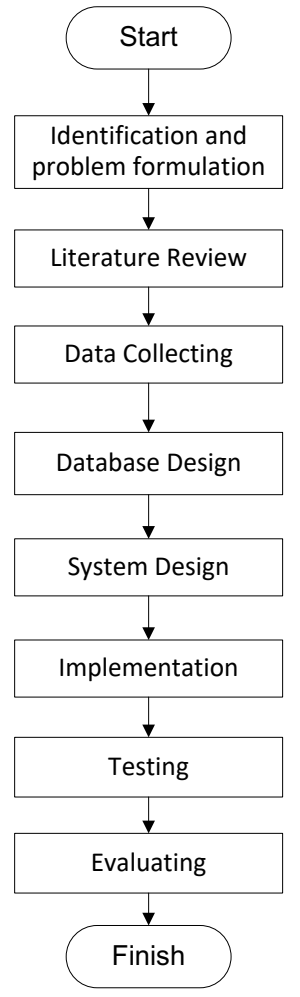

Figure 1 Flowchart of Work Design 
B. System flowchart

Figure 2 describes how the user interacts with the system and the expected functionality of a system.

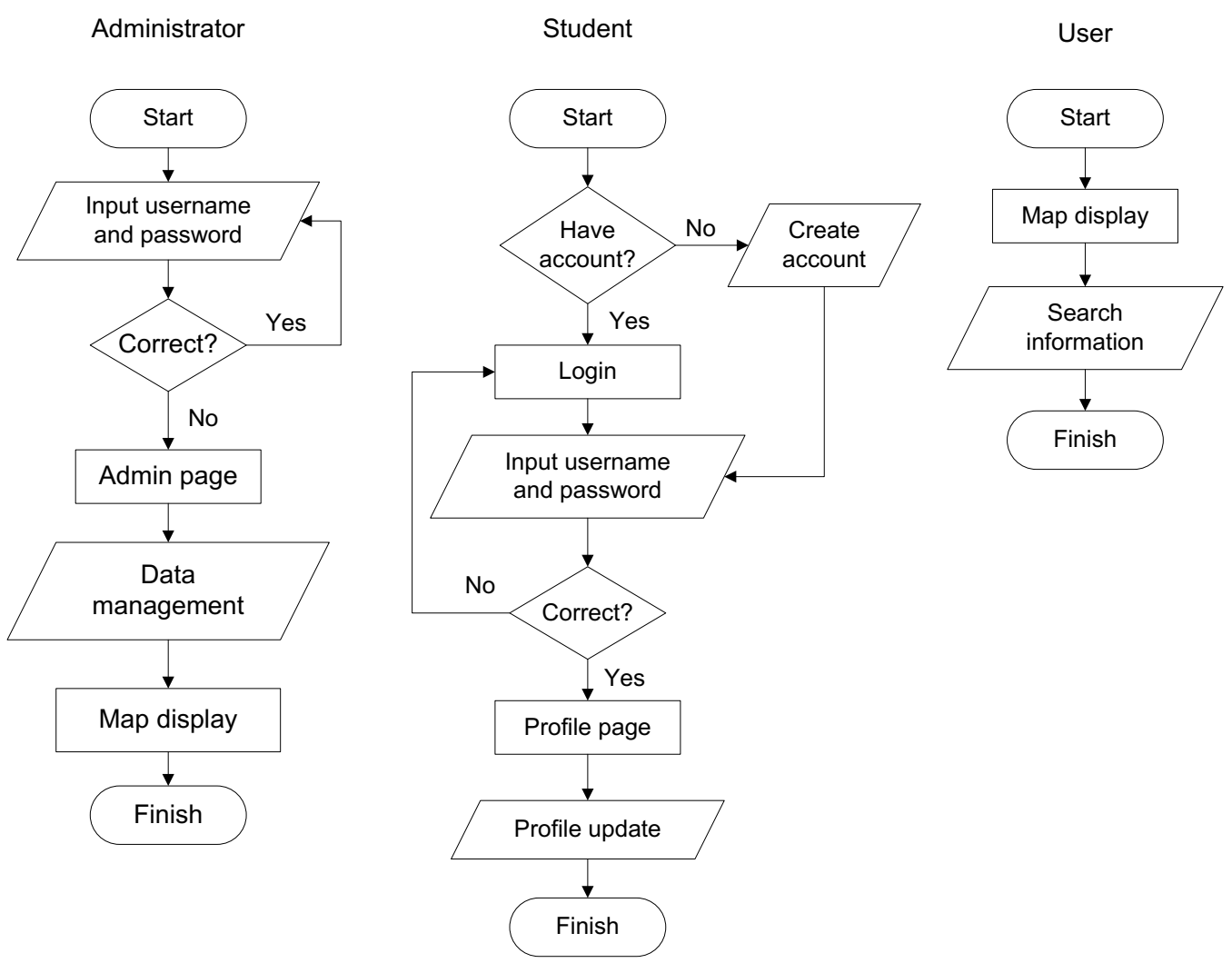

Figure 2. System Flowchart

\section{Use Case Diagram}

Figure 3 explains how the user interacts with the system and describes the expected functionality of a system that is displayed in the form of a Use Case Diagram.

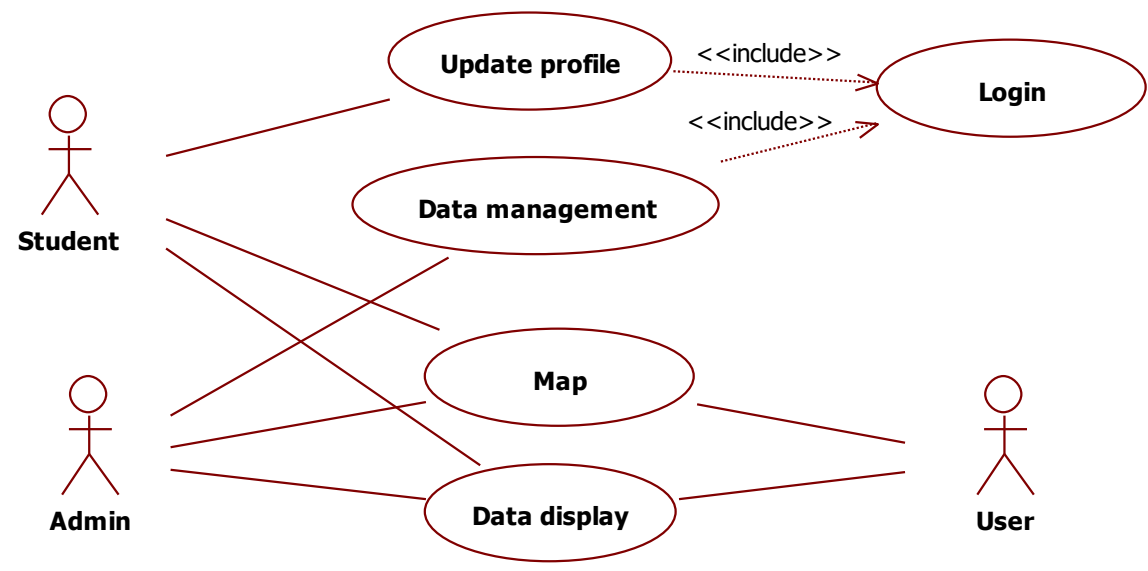

Figure 3. Use Case Diagram 


\section{Result and Discussion}

In part IV, it discusses the implementation of the application of the South Aceh Polytechnic Student Origin Mapping Information System. The purpose of implementing this system is to ensure that the software created can work effectively and efficiently as expected. The South Aceh Polytechnic Student Origin Mapping Information System application was built using LeafletJS to display maps and the CodeIgniter 3 Framework for the Media Interface.

\section{A. Login Page}

Figure 4 is an implementation of the login page. On this page there is a login form for admin and student users, asked to fill in the username and password in the fields provided.

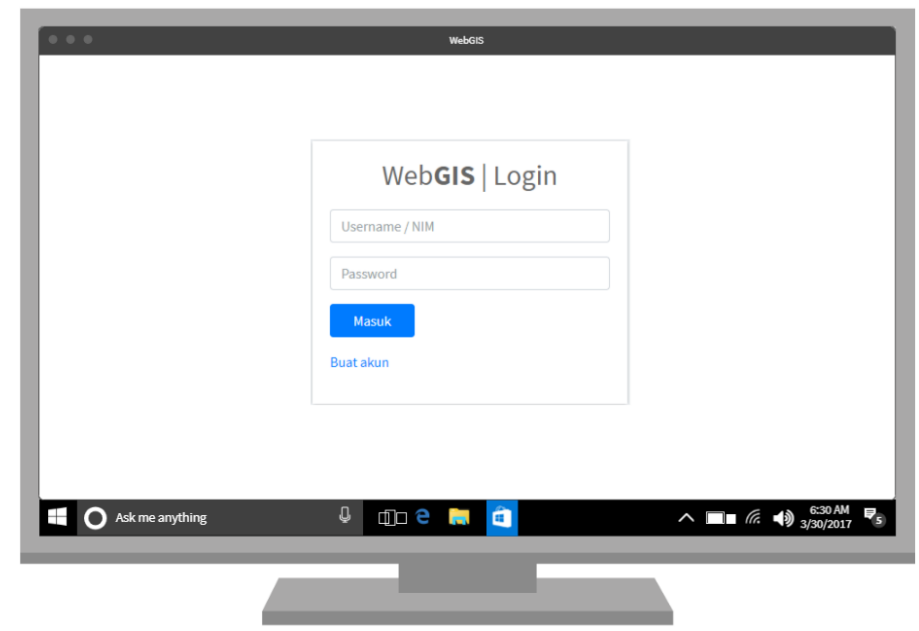

Figure 4. Login Page

B. Registration Page

Figure 5 is the implementation of the registration page. On this page there is a registration form where students who do not have an account are asked to fill in data such as name, username in this case using NIM, and password in the available fields.

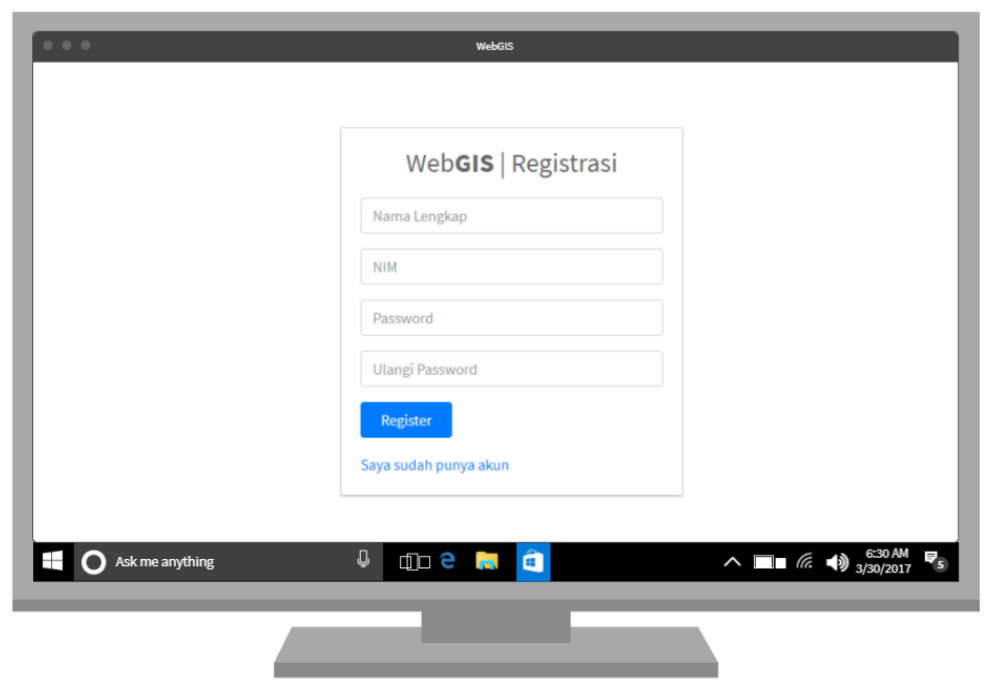

Figure 5. Registration Page

C. Admin Dashboard

Figure 6 is the implementation of the admin dashboard page. Admin can manage data such as adding, changing, deleting and searching for data on available information. 


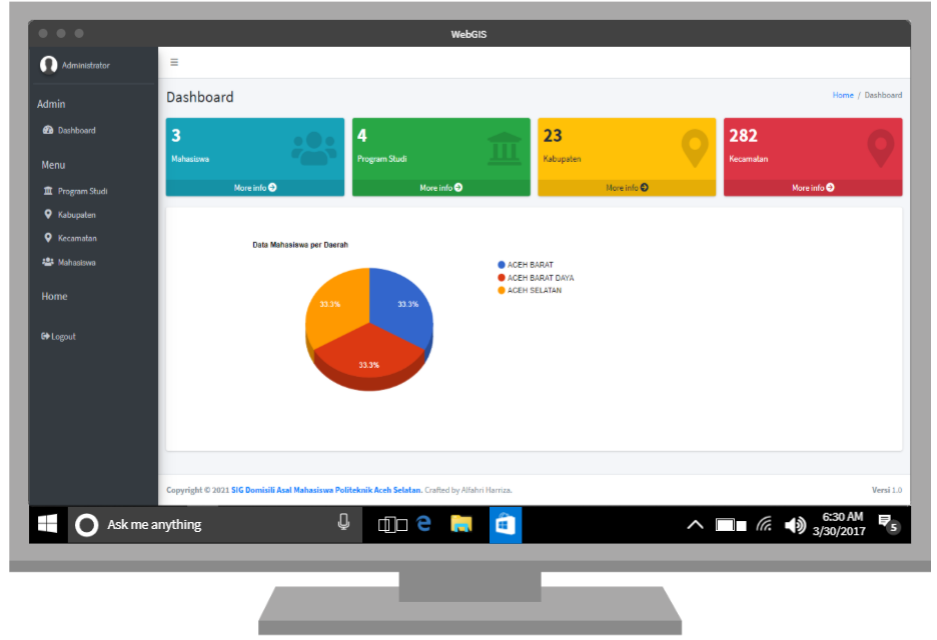

Figure 6. Admin Dashboard

D. Students' Profile Page

Figure 7 is the implementation of the students' profile page. Here students can update their own data such as name, number, study program and domicile of origin.

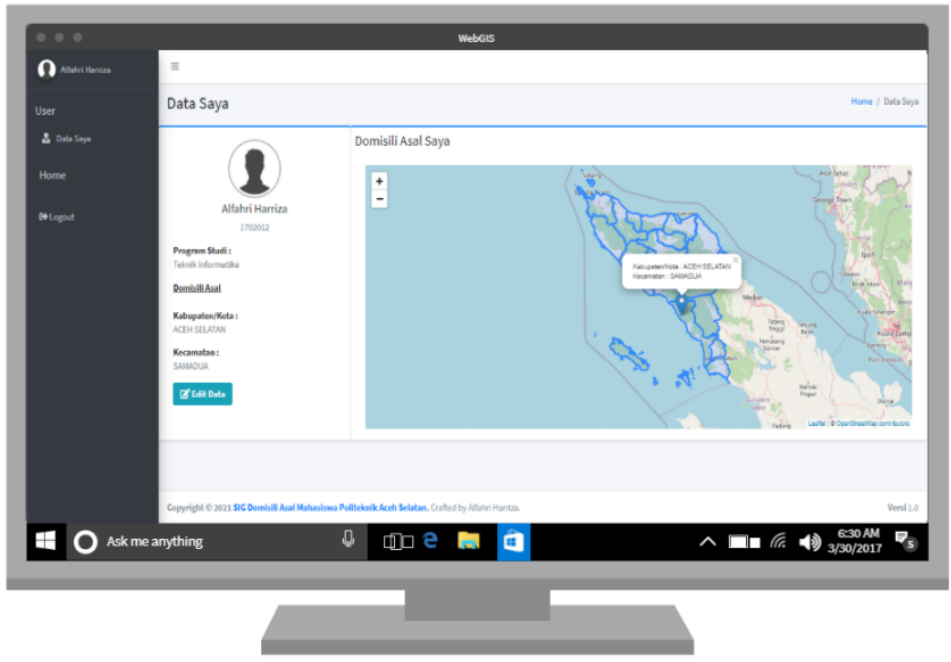

Figure 7. Students' Profile Page

E. Homepage

Figure 8 is the implementation of the home page. Here users can get information about the homeland distribution of South Aceh Polytechnic students. The map marked with a marker indicates that there are South Aceh Polytechnic students from the area. 


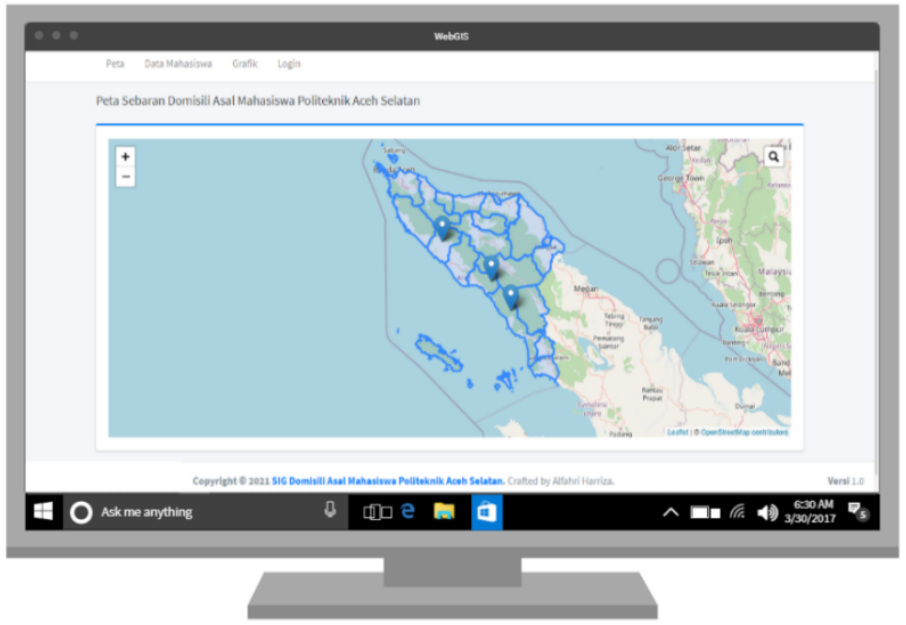

Figure 8. Homepage

F. Blackbox Test

The Blackbox test results show that the test results can run well and smoothly. The test results are shown in Table 1.

Table 1. Blackbox Test

\begin{tabular}{lll}
\hline Menu & Indicators & Test Result \\
\hline Login & $\begin{array}{l}\text { When the user inputs the username and password, the user } \\
\text { successfully enters the system. }\end{array}$ & Success \\
\hline Registration & $\begin{array}{l}\text { Students who do not have an account can register to create } \\
\text { their own account. }\end{array}$ & Success \\
\hline Dashboard & Administrators can manage the data contained in the system. & Success \\
\hline User Profil & Students can view and update their own data. & Success \\
\hline Peta & $\begin{array}{l}\text { Users can get information about the distribution of students' } \\
\text { areas of origin. }\end{array}$ & Success \\
& &
\end{tabular}

\section{Conclussion}

From the results and discussions that have been presented, it can be concluded that the geographic information system for mapping student homeland that has been created can display information about the distribution of student homeland in the form of an interactive online map. The student homeland distribution map can be used for evaluation in order to increase the promotion for future students at the Politeknik Aceh Selatan in the neighborhood.

\section{References}

[1] S. H. Sumantri, M. Supriyatno, S. Sutisna, and I. D. K. K. Widana, "Sistem Informasi Geografis (Geographic Information System) Kerentanan Bencana," 2019.

[2] Asmaidi, S. F. Junanda, and D. Safitri, "Sistem Informasi Penjadwalan Laboratorium Berbasis Web (Studi Kasus : Laboratorium Multimedia Politeknik Aceh Selatan)," METHOMIKA J. Manaj. Inform. dan Komputerisasi Akunt., vol. 2, no. 2, 2018.

[3] R. A. Canover, "Sistem Informasi Daerah Asal Mahasiswa Politeknik Negeri Batam Berbasis WebGIS (Studi Kasus : Jurusan Manajemen Bisnis),” Politeknik Negeri Batam, 2015.

[4] F. Masykur, "Implementasi Sistem Informasi Geografis Menggunakan Google Maps API Dalam 
Pemetaan Asal Mahasiswa," SIMETRIS, vol. 5, no. 2, pp. 181-186, 2014.

[5] P. Guranti and Affandy, "Sistem Informasi Geografis Pemetaan Domisili Asal Mahasiswa Universitas Dian Nuswantoro Berbasis Google Maps API," J. Inf. Syst., vol. 2, no. 1, pp. 134-143, 2017.

[6] U. Hujjati, Z. Musliyana, and M. Fadhli, "Perancangan Sistem Informasi Geografis Jumlah Mahasiswa Universitas Ubudiyah Indonesia Berbasis Web," J. Informatics Comput. Sci., vol. 6, no. 2, pp. 129 $136,2020$. 